\title{
Will introduction of ARNI reduce the need of device therapy in heart failure with reduced ejection fraction?
}

\author{
Navjyot Kaur, CR Pruthvi and Manojkumar Rohit
}

\section{Background}

The last two decades saw major therapeutic advancements in the field of heart failure with reduced ejection fraction (HFrEF). While implantable cardioverterdefibrillator (ICD) and cardiac resynchronization therapy (CRT) became part of HFrEF therapy in the first decade of twentieth century, the second decade marked the introduction of angiotensin receptor neprilysin inhibitor (ARNI) in optimal medical therapy (OMT) for HFrEF. ICD prevents sudden cardiac deaths (SCDs), and CRT improves left ventricular ejection fraction (LVEF), reverses cardiac remodeling, and decreases heart failure (HF)-related hospitalizations and mortality. While ICD prevents $50-60 \%$ SCDs but not all, the CRT has shown its consistent efficacy only in selected subset of HFrEF patients and has a non-responder rate of 30\% [1]. The novel pharmacological therapy ARNI reduced the HFrelated mortality and hospitalization when compared with well-established angiotensin-converting enzyme inhibitor (ACEi) [2]. Though ARNI reduced mortality both due to HF progression and SCD, it was associated with a higher incidence of symptomatic hypotension. In this opinion paper, we discuss the two very recent contemporary therapies (device therapy and ARNI) for HFrEF, the gap in evidence, and the projected role of each therapy in coming years.

\section{Important trials \\ ICD}

The role of ICD in primary prevention was established by Multicenter Automatic Defibrillator Implantation II (MADIT II) and Sudden Cardiac Death-Heart Failure

\footnotetext{
* Correspondence: cardiopgimerchd@gmail.com Cardiology Unit II, Department of Cardiology, Level-3, Faculty Offices, Advanced Cardiac Center, Post Graduate Institute of Medical Education \& Research, Sector-12, Chandigarh 160012, India
}

trial (SCD-HeFT) trials [3]. While MADIT II included only ischemic patients with LVEF $\leq 35 \%$, the SCD-HeFT trial included patients with both ischemic and nonischemic etiology. However, Prophylactic Defibrillator Implantation in Patients with Non-ischemic Dilated Cardiomyopathy (DEFINITE) and Danish Study to Assess the Efficacy of ICDs in Patients with Non-Ischemic Systolic Heart Failure on Mortality (DANISH) trials failed to show a significant reduction in total mortality in nonischemic cardiomyopathy (NICM), though the SCDs were reduced in both trials [1]. In contrast to SCDHeFT where the use of beta blockers was less than $70 \%$, more than $85 \%$ of patients in DEFINITE and DANISH trials were on beta blockers [4]. A recent meta-analysis of 06 randomized controlled trials (RCTs) involving 2970 patients with NICM revealed 23\% risk reduction in all-cause mortality with ICD [5], and hence, the presentday guidelines recommend the use of ICDs for primary prevention in HFrEF (New York Heart Classification (NYHA)-II/III) irrespective of the etiology. However, ICD is not advisable in patients with NYHA class IV symptoms or whose expected meaningful survival is less than 1 year.

\section{CRT}

Electromechanical dyssynchrony leads to nonsynchronized left ventricular contraction, adverse cardiac remodeling, and increased myocardial energy expenditure. While Multisite stimulation in Cardiomyopathy (MUSTIC-SR), Multicenter In Sync Randomized Clinical Evaluation (MIRACLE), and CONTAK CD trials showed a significant improvement in NYHA functional class and peak oxygen consumption (pVO2) in selected patients of HFrEF (NYHA classes III and IV) with CRT, the subsequent two trials, Cardiac Resynchronization in Heart Failure Trial (CARE HF) and Comparison of Medical
Springer Open

(c) The Author(s). 2021 Open Access This article is licensed under a Creative Commons Attribution 4.0 International License, which permits use, sharing, adaptation, distribution and reproduction in any medium or format, as long as you give appropriate credit to the original author(s) and the source, provide a link to the Creative Commons licence, and indicate if changes were made. The images or other third party material in this article are included in the article's Creative Commons licence, unless indicated otherwise in a credit line to the material. If material is not included in the article's Creative Commons licence and your intended use is not permitted by statutory regulation or exceeds the permitted use, you will need to obtain permission directly from the copyright holder. To view a copy of this licence, visit http://creativecommons.org/licenses/by/4.0/. 
Therapy, Pacing, and Defibrillation in Heart Failure (CHAMPION) trials, provided evidence for a reduction in mortality and HF hospitalizations in same functional class of patients with HFrEF [6]. CRT in moderate to severely symptomatic HFrEF patients reduces the all-cause mortality by $28 \%$ and HF hospitalizations by $37 \%$ [7]. The role of CRT in mildly symptomatic patients (NYHA II) was established by Resynchronization Reverse Remodelling in Systolic Left Ventricular Dysfunction trial (REVERSE), MADIT-CRT, and Resynchronization/Defibrillation for Ambulatory Heart Failure Trial [RAFT] trials [6]. Based on available evidence, the present guidelines on HFrEF give the highest level recommendation for CRT in patients with LVEF $\leq 35 \%$ who have left bundle branch block (LBBB) and wide QRS $\geq 150 \mathrm{~ms}$ and remain symptomatic (NYHA class II, III, ambulatory IV) despite receiving OMT [6]. It is noteworthy that all the above mentioned RCTs were conducted between 2000 and 2010, when ARNI was not part of OMT. Moreover, the CRT has shown maximum and most consistent benefit only in a subset of patients with HFrEF and has a non-response rate of $30 \%$ even in this highly selected subgroup. Further, the CRT failed to show a consistent positive impact in HFrEF patients with non-LBBB and narrow QRS.

\section{ARNI}

The pathophysiology of HFrEF is marked by upgradation of the renin-angiotensin-aldosterone system and by down-gradation of cardio-protective molecules like natriuretic peptides. ARNI, the combination of angiotensin receptor blocker (ARB) and neprilysin inhibitor (sacubitril/valsartan), proved superior to wellestablished angiotensin-converting enzyme inhibitor (ACEi) and showed a $20 \%$ relative risk reduction in the primary endpoint of cardiovascular $(\mathrm{CV})$ death and $\mathrm{HF}$ hospitalization and $16 \%$ reduction in all-cause mortality in the landmark PARADIGM-HF trial [2]. Both SCDs and deaths due to HF progression were reduced equally. Soon after, the American and European guidelines $[8,9]$ included ARNI into the pharmacological management of symptomatic HFrEF patients (NYHA II-IV) on an outpatient basis. PIONEER-HF trial demonstrated the safety of introduction of ARNI in patients with acute decompensated heart failure (after stabilization) [10]. The most significant side effect reported with ARNI has been symptomatic hypotension which may hamper the uptitration of the drug to target dosages and lead to high rates of non-compliance and non-adherence in realworld scenarios. There are concerns about decreased clearance and deposition of beta amyloid peptides in the brain due to neprilysin inhibition with long-term use of ARNI. Table 1 summarizes the major RCTs done on ARNI in the last decade.

\section{CRT and ARNI: cardiac remodeling}

CRT is considered one of the most powerful cardiac remodeling agents, second only to beta blockers [4]. It reverses the adverse cardiac remodeling, decreases LV and left atrial dimensions, and improves LVEF and functional mitral regurgitation, and the same has been co-related with positive clinical outcomes in MADIT-CRT and REVERSE trials [6]. The effect of ARNI on cardiac remodeling has been recently illustrated in PROVE HF trial [11] wherein ARNI over a period of 12 months improved LVEF by $9.4 \%$ and reduced LV end-diastolic volume index, LV end-systolic volume index, and left atrial volume index. A recent Italian observational SAVE ICD study by Federico Guerra revealed that after 6 months of treatment with ARNI, 25\% of patients with ICD for primary prevention had LVEF $\geq 35 \%$ [12].

We cannot compare the absolute effect on cardiac remodeling between two modalities because of the heterogeneities of populations studied. Also, the CRT is offered over and above the OMT and reduction in LV volumes and improvement in LVEF can be at the best considered add-on, rather than an absolute effect. On the other hand, ARNI has proven to be effective when compared with another well-established RAAS blocking agent [2].

\section{CRT and ARNI: do they reduce the risk of SCD and ventricular arrhythmias (VA)?}

The CHAMPION trial failed to show significant mortality benefit of CRT-D over CRT-P [1]. In a more recent CeRtiTude cohort study, the rate of SCD was no different in two groups of patients with CRT-P and CRT-D at 2-year follow-up, despite the fact that the patients in the former group were sicker and older and had multiple comorbidities [13]. A review by Barra et al. in 2019 revealed that the risk of SCD in CRT patients has reduced more than fourfold over the last 20 years; the rate of decline in mortality including SCD has been more in the CRT-P group and it related closely to increased LVEF, increased use of beta blockers, decreased QRS duration, and decreased use of antiarrythmic drugs [14]. The PARADIGM trial showed an impressive reduction of $22 \%$ in the rate of SCDs [2]. de Diego et al. [15] and Martens et al. [16] revealed a significant reduction in sustained and non-sustained VAs and appropriate ICD shocks in the ARNI group and the latter also documented better pacing parameters of ICDs in patients on ARNI [17]. Sacubitril/valsartan reduces the arrhythmia burden primarily by improvement in cardiac remodeling, though the smaller studies have also illustrated a decrease in QRS duration, QTc interval, and mechanical dispersion as assessed by LV global longitudinal strain imaging [18]. 
Table 1 Summary of major randomized controlled trials on angiotensin receptor neprilysin inhibitor

\begin{tabular}{|c|c|c|c|c|c|}
\hline Trial & Intervention & Comparator & Inclusion criteria & Primary endpoints & Outcomes \\
\hline $\begin{array}{l}\text { PARADI } \\
\text { FM-HF } \\
(2014) \\
(n=8399) \\
\text { F/up } 27 \\
\text { months }\end{array}$ & $\begin{array}{l}\text { Sacubitril/ } \\
\text { vvalsartan }\end{array}$ & Enalapril & $\begin{array}{l}\text {-LVRF } \leq 35 \\
\text {-NYHA classes II-IV } \\
\text {-Elevated NP }\end{array}$ & $\begin{array}{l}\text { Composite of CVD or HF } \\
\text { hospitalization }\end{array}$ & $\begin{array}{l}\text { Primary endpoint } \\
\mathrm{HR}=0.80(0.73-0.87) \\
P=0.0000002 \\
\mathrm{CVD} \\
\mathrm{HR}=0.80(0.71-0.89) \\
P=0.00004 \\
\text { All-cause mortality } \\
\mathrm{HR}=0.84(0.76-0.93) \\
P<0.0001 \\
\text { Symptomatic hypotension }(14 \% \text { vs } \\
9.2 \% ; P<0.001)\end{array}$ \\
\hline $\begin{array}{l}\text { TITRATION } \\
(2016) \\
(n=498) \\
\text { F/up 12 } \\
\text { weeks }\end{array}$ & $\begin{array}{l}\text { Condensed } \\
\text { regimen (full } \\
\text { dose of ARNI by } \\
3 \text { weeks) }\end{array}$ & $\begin{array}{l}\text { Comparator } \\
\text { regimen (full } \\
\text { dose of ARNI by } \\
6 \text { weeks) }\end{array}$ & $\begin{array}{l}\text { LVEF } \leq 35 \% \\
\text { NYHA classes } \|-I V\end{array}$ & $\begin{array}{l}\text { Adverse events (hypotension, } \\
\text { renal dysfunction, hyperkalemia, } \\
\text { angioedema) }\end{array}$ & No significant difference \\
\hline $\begin{array}{l}\text { PIONEER- } \\
\text { HF }(2019) \\
(n=881) \\
\text { F/up } 8 \\
\text { weeks }\end{array}$ & $\begin{array}{l}\text { Sacubitril/ } \\
\text { valsartan }\end{array}$ & Enalapril & $\begin{array}{l}\text { LVEF } \leq 40 \% \\
\text { Elevated NP } \\
\text { Hospitalized for ADHF }\end{array}$ & $\begin{array}{l}\text { Time-averaged change of NT- } \\
\text { proBNP }\end{array}$ & $\begin{array}{l}\text { Primary endpoint } \\
\text { HR } 0.71(0.63-0.81), P<0.05 \\
\text { HF rehospitalization } 8.0 \% \text { vs. } 13.8 \%, P \\
<0.05\end{array}$ \\
\hline $\begin{array}{l}\text { PARA } \\
\text { MOUNT } \\
(2012) \\
(n=301) \\
\text { F/up 12 } \\
\text { weeks }\end{array}$ & $\begin{array}{l}\text { Sacubitril/ } \\
\text { valsartan }\end{array}$ & Valsartan & $\begin{array}{l}\text { LVEF } \geq 45 \% \\
\text { NYHA classes II-III } \\
\text { Elevated NP }\end{array}$ & $\begin{array}{l}\text { Change in NT-pro BNP from } \\
\text { baseline }\end{array}$ & $\begin{array}{l}\text { Significant change in favor of ARNI: } \\
\text { Ratio } 0.77(0.64-0.92)\end{array}$ \\
\hline $\begin{array}{l}\text { PARAGON- } \\
\text { HF (2019) } \\
(n=4822) \\
\text { F/up } 35 \\
\text { months }\end{array}$ & $\begin{array}{l}\text { Sacubitril/ } \\
\text { valsartan }\end{array}$ & Valsartan & $\begin{array}{l}\text { LVEF } \geq 45 \% \\
\text { NYHA classes II-III } \\
\text { Elevated NP }\end{array}$ & $\begin{array}{l}\text { Composite of HF hospitalizations } \\
\text { and CVDs }\end{array}$ & $\begin{array}{l}\text { Non-significant } \\
\text { Relative risk } 0.87(0.75-1.01)\end{array}$ \\
\hline $\begin{array}{l}\text { EVALUATE- } \\
\text { HF (2019) } \\
(n=464) \\
\text { F/up } 12 \\
\text { weeks }\end{array}$ & $\begin{array}{l}\text { Sacubitril/ } \\
\text { valsartan }\end{array}$ & Enalapril & $\begin{array}{l}\text { LVEF } \leq 40 \% \\
\text { NYHA classes I-III } \\
\text { History of hypertension }\end{array}$ & $\begin{array}{l}\text { Aortic characteristic impedance } \\
\text { (Zc) }\end{array}$ & $\begin{array}{l}\text { Non-significant difference in two } \\
\text { groups }\end{array}$ \\
\hline $\begin{array}{l}\text { PRIME } \\
(2019) \\
(n=118) \\
\text { F/up } 12 \\
\text { months }\end{array}$ & $\begin{array}{l}\text { Sacubitril/ } \\
\text { valsartan }\end{array}$ & Valsartan & $\begin{array}{l}\text { LVEF } 25-50 \% \\
\text { NYHA classes I-III } \\
\text { Chronic functional MR } \\
\text { (EROA > } 0.1 \mathrm{~cm}^{2} \\
\text { despite optimal } \\
\text { medical therapy) }\end{array}$ & Change in EROA & $\begin{array}{l}\text { Significant decrease in EROA ( } \nabla \\
\left.0.04 \mathrm{~cm}^{2}\right) \text {, regurgitant volume }(\nabla 7.3 \\
\mathrm{ml}) \text {, LVEDVI }(\nabla 7.01 \mathrm{ml})\end{array}$ \\
\hline $\begin{array}{l}\text { PROVE-HF } \\
(2019) \\
(n=794) \\
\text { F/up 12 } \\
\text { months }\end{array}$ & $\begin{array}{l}\text { Sacubitril/ } \\
\text { valsartan }\end{array}$ & ACEi/ARB & $\begin{array}{l}\text { LVEF } \leq 40 \% \\
\text { NYHA II-IV }\end{array}$ & $\begin{array}{l}\text { Correlation between change in } \\
\text { NT-pro BNP and remodeling } \\
\text { (LVEF, LVEDVi, LVESVi, LAVi, E/E/e' } \\
\text { at } 12 \text { months }\end{array}$ & $\begin{array}{l}\text { Significant correlations observed } \\
\text { between the change in NT-proBNP } \\
\text { concentration and all cardiac remodel- } \\
\text { ing parameters }\end{array}$ \\
\hline
\end{tabular}

ACEi Angiotensin-converting enzyme inhibitor, ADHF Acute decompensated heart failure, ARB Angiotensin receptor blocker, ARNI Angiotensin receptor neprolysin inhibitor, CV Cardiovascular, CVD Cardiovascular death, E/e' Ratio of early mitral diastolic filling velocity/early diastolic mitral annular velocity, EROA Effective regurgitant orifice area, EVALUATE-HF Effect of Sacubitril-Valsartan Versus Enalapril on Aortic Stiffness in Patients with Heart Failure and Reduced Ejection Fraction, F/up Follow-up, HF Heart failure, HR Hazard ratio, LAVi Left atrial volume index, LVEDVi LV end-diastolic volume index, LVEF Left ventricular ejection fraction, LVESVi LV end-systolic volume index, MR Mitral regurgitation, NP Natriuretic peptide, NT-proBNP N-terminal-pro B-type NP, NYHA New York Heart Association, PARADIGMHF Prospective comparison of Angiotensin Receptor-Neprilysin Inhibitor (ARNI) with ACEl to Determine Impact on Global Mortality and morbidity in Heart Failure, PARAGON-HF Prospective Comparison of ARNI with ARB Global Outcomes in HF With Preserved Ejection Fraction, PARAMOUNT Prospective comparison of ARNI with ARB on Management Of heart failure with preserved ejection fraction, PIONEER-HF Comparison of Sacubitril-Valsartan versus Enalapril on Effect on NT-proBNP in Patients Stabilized from an Acute Heart Failure Episode, PRIME Pharmacological Reduction of Functional, Ischemic Mitral Regurgitation, PROVE-HF Prospective Study of Biomarkers, Symptom Improvement and Ventricular Remodeling During Entresto Therapy for Heart Failure, RFT Renal function test, $\nabla$ Change

\section{The GAP in evidence}

CRT and ICD have shown to reduce mortality and morbidity in a selected subgroup of HFrEF patients who remain symptomatic while on OMT. ARNI improves clinical outcomes as compared to the well-established ACEi. Whether these devices would have significant positive clinical outcomes when used along with ARNI is still not known. In the case of ICDs, the meaningful 
reduction of mortality when used for primary prevention can only occur if the baseline risk of SCD is $>35 \%$ or the rate of $\mathrm{SCD} \geq 1.2 \%$ per year [1]. With the increased use of beta blockers, the absolute risk of SCDs reduces and the additional ICD may have insignificant benefit [1, 4]. Similarly, with the addition of ARNI, the absolute CV mortality may reduce with no added benefit of any device therapy. Since ARNI is associated with a significantly increased risk of hypotension, compliance with the drug and achievement of target dosage may be an issue in real-world scenario especially in the Asian population. Likewise, the clinical benefit achieved with suboptimal dosages needs to be studied in prospective registries.

\section{ARNI and devices: two complementary therapies in HFrEF}

ARNI can be used in all symptomatic patients of HFrEF while CRT has shown maximum benefit in patients with LBBB and wide QRS. It causes time-dependent improvement in LVEF [11, 12], may reduce the need of ICD for primary prevention [12], and has shown to improve the biventricular pacing by reducing ventricular ectopy and thus can improve the percentage of responders in the CRT group. ARNI may also reduce the appropriate ICD therapy in patients with HFrEF by reducing VAs. However, till the time a robust evidence draws an entirely different conclusion, we should follow the present guidelines on the appropriate use of ICD, CRT, and ARNI in patients with HFrEF, though we may use ARNI more often as part of OMT with an aim to achieve the best possible benefit. Figure 1 illustrates the respective role of various therapies in the management of HFrEF.

\section{Conclusion}

ARNI and device therapy for HFrEF are two complementary therapies. While ARNI and CRT improve LVEF, reduce LV volumes, and produce significant improvement in cardiovascular mortality and HF hospitalizations, the ICDs reduce the additional risk of SCD in selected patients. Given the evidence, the ARNI shall be the future foundation of OMT for HFrEF, with CRT/

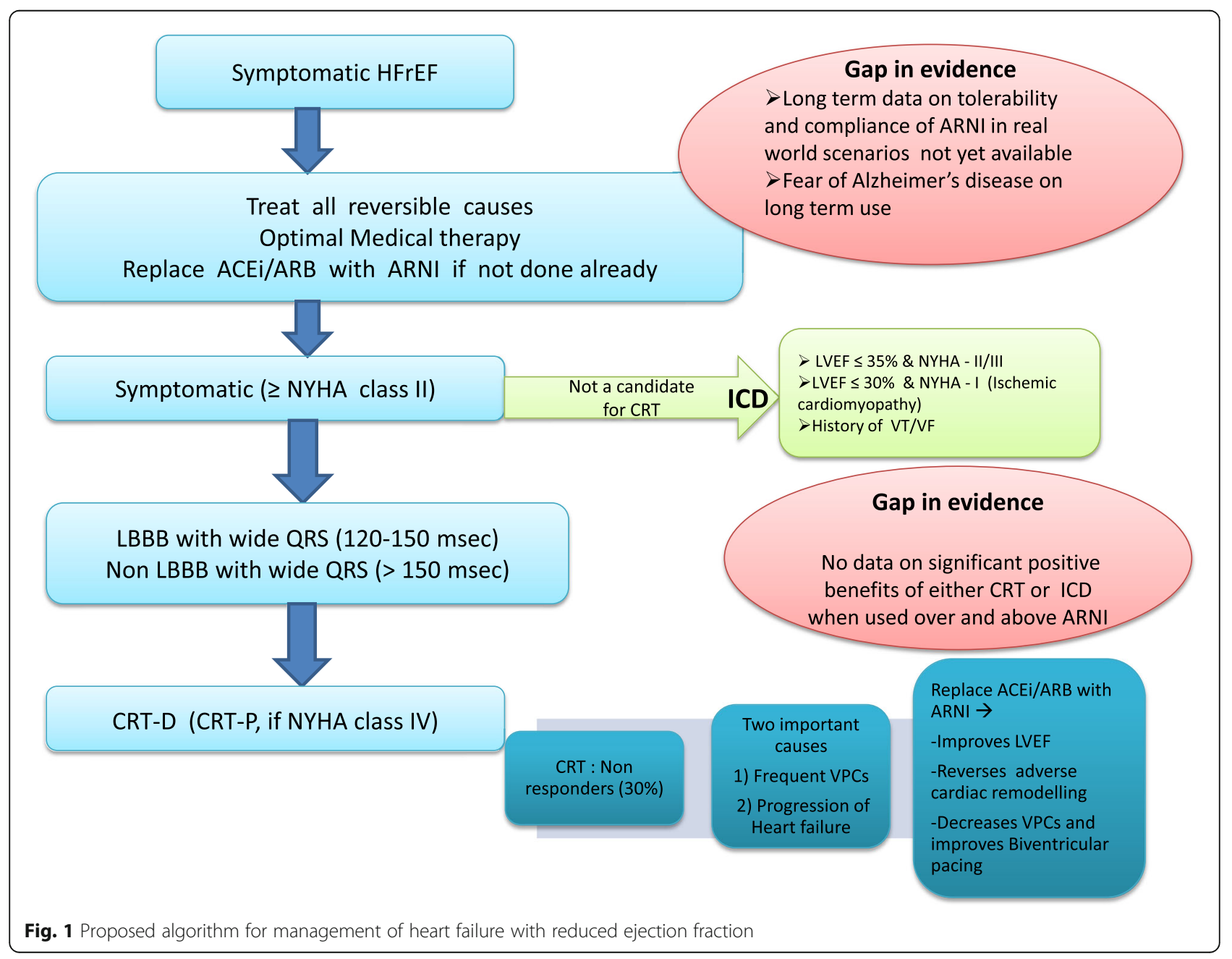


ICD reserved for special situations where patients remain symptomatic while on OMT. The role of CRT/ ICD in the era of ARNI needs to be re-established since the definition of OMT stands changed with much better and potent pharmacological therapy.

\section{Abbreviations}

ACEi: Angiotensin-converting enzyme inhibitor; ARB: Angiotensin receptor blocker; ARNI: Angiotensin receptor neprilysin inhibitor; CRT: Cardiac resynchronization therapy; CV: Cardiovascular; HF: Heart failure; HFrEF: Heart failure with reduced ejection fraction; ICD: Implantable cardioverterdefibrillator; LBBB: Left bundle branch block; NICM: Non-ischemic dilated cardiomyopathy; NYHA: New York Heart Classification; OMT: Optimal medical therapy; pVO2: Peak oxygen consumption; RCTs: Randomized controlled trials; SCDs: Sudden cardiac deaths

\section{Acknowledgements}

Not applicable

\section{Authors' contributions}

NK: planning, conceptualization, review of the literature, and writing the original draft preparation; PCR: conceptualizationn, writing the original draft preparation, and final review; MKR: planning, conceptualization, methodology, supervision, final review, and editing. All authors read and approved the final manuscript.

\section{Funding}

No financial support was taken from any source by any of the authors.

\section{Availability of data and materials}

Not applicable for the above-said reasons

\section{Declarations}

\section{Ethics approval and consent to participate}

This particular manuscript is not a study or case report nor does it involves any human/animal trial or plant study. It is a commentary on contemporary literature on heart failure therapies. However, the ethics committee of our institution approves the submission of this article for publication.

\section{Consent for publication}

Not applicable for the above-said reasons

\section{Competing interests}

The authors declare that they have no competing interests.

Received: 5 January 2021 Accepted: 1 March 2021

Published online: 16 March 2021

\section{References}

1. Levy WC (2017) Should nonischemic CRT candidates receive CRT-P or CRT D? J Am Coll Cardiol 69(13):1679-1682

2. McMurray JJ, Packer M, Desai AS, Gong J, Lefkowitz MP, Rizkala AR, PARADI GM-HF Investigators and Committees et al (2014) Angiotensin-neprilysin inhibition versus enalapril in heart failure. N Engl J Med 371(11):993-1004

3. Tung R, Zimetbaum P, Josephson ME (2008) A critical appraisal of implantable cardioverter-defibrillator therapy for the prevention of sudden cardiac death. J Am Coll Cardiol 52(14):1111-1121

4. Carlos de D, Gonzalez-Torres L, Jose Maria N et al (2018) Advances in pharmacological therapy in reduced left ventricular heart failure patients with implantable cardiac defibrillator and cardiac resynchronization. Clin Cardiol J 2(1):1-5

5. Golwala H, Bajaj NS, Arora G, Arora P (2017) Implantable cardioverterdefibrillator for nonischemic cardiomyopathy: an updated meta-analysis. Circulation 135(2):201-203. https://doi.org/10.1161/CIRCULATIONAHA.116.02 6056 Epub 2016 Dec 19. PMID: 27993908: PMCID: PMC5416382

6. Linde C, Ellenbogen K, McAlister FA (2012) Cardiac resynchronization therapy (CRT): clinical trials, guidelines, and target populations. Heart Rhythm 9(8 Suppl):S3-S13
7. Rossi A, Rossi G, Piacenti M et al (2008) The current role of cardiac resynchronization therapy in reducing mortality and hospitalization in heart failure patients: a meta-analysis from clinical trials. Heart Vessels 23:217-223

8. Yancy CW, Jessup M, Bozkurt B, Butler J, Casey DE Jr, Colvin MM et al (2017) 2017 ACC/AHA/HFSA focused update of the 2013 ACCF/AHA guideline for the management of heart failure: a report of the American College of Cardiology/American Heart Association task force on clinical practice guidelines and the Heart Failure Society of America. Circulation 136(6):e137e161

9. Ponikowski P, Voors AA, Anker SD, Bueno H, Cleland JG, Coats AJ et al (2016) 2016 ESC quidelines for the diagnosis and treatment of acute and chronic heart failure: the task force for the diagnosis and treatment of acute and chronic heart failure of the European Society of Cardiology (ESC). Eur J Heart Fail 18(8):891-975

10. Velazquez EJ, Morrow DA, DeVore AD, Duffy Cl, Ambrosy AP, McCague K et al (2019) Angiotensin-neprilysin inhibition in acute decompensated heart failure. N Engl J Med 380(6):539-548

11. Januzzi JL Jr, Prescott MF, Butler J, Felker GM, Maisel AS, McCague K et al (2019) Association of change in N-terminal pro-B-type natriuretic peptide following initiation of sacubitril-valsartan treatment with cardiac structure and function in patients with heart failure with reduced ejection fraction. JAMA 322(11):1-11

12. SAVE-ICD: for some, sacubitril/valsartan may obviate need for ICD Medscape, 2020.

13. Marijon E, Leclercq C, Narayanan K, Boveda S, Klug D, Lacaze Gadonneix J et al (2015) Causes-of-death analysis of patients with cardiac resynchronization therapy: an analysis of the CeRtiTuDe cohort study. Eur Heart J 36(41):2767-2776

14. Barra S, Providência R, Narayanan K, Boveda S, Duehmke R, Garcia R et al (2019) Time trends in sudden cardiac death risk in heart failure patients with cardiac resynchronization therapy: a systematic review. Eur Heart J. https://doi.org/10.1093/eurheartj/ehz773

15. de Diego C, González-Torres L, Núñez JM, Centurión Inda R, MartinLangerwerf DA, Sangio AD, et al (2018) Effects of angiotensin-neprilysin inhibition compared to angiotensin inhibition on ventricular arrhythmias in reduced ejection fraction patients under continuous remote monitoring of implantable defibrillator devices. Heart Rhythm 15(3):395-402.

16. Martens $P$, Nuyens D, Rivero-Ayerza M, Van Herendael H, Vercammen J, Ceyssens W, et al (2019) Sacubitril/valsartan reduces ventricular arrhythmias in parallel with left ventricular reverse remodeling in heart failure with reduced ejection fraction. Clin Res Cardiol 108(10):1074-082.

17. Vecchi AL, Abete R, Marazzato J, lacovoni A, Mortara A, De Ponti R, Senni M (2020) Ventricular arrhythmias and ARNI: is it time to reappraise their management in the light of new evidence? Heart Fail Rev. https://doi.org/1 0.1007/s10741-020-09991-3. Epub ahead of print.

18. Valentim Gonçalves A, Pereira-da-Silva T, Galrinho A et al (2019) Antiarrhythmic effect of sacubitril-valsartan: cause or consequence of clinical improvement? J Clin Med 8(6):869 Published 2019 Jun 18.

\section{Publisher's Note}

Springer Nature remains neutral with regard to jurisdictional claims in published maps and institutional affiliations.

\section{Submit your manuscript to a SpringerOpen ${ }^{\circ}$ journal and benefit from:}

- Convenient online submission

- Rigorous peer review

- Open access: articles freely available online

- High visibility within the field

- Retaining the copyright to your article

Submit your next manuscript at $>$ springeropen.com 